\title{
Paleoconservatism and the Issue of Immigration and Multiculturalism
}

\begin{abstract}
This article deals with paleoconservative attitudes toward the issue of immigration to the United States and the problem of multiculturalism and assimilation on American soil. Representatives of paleoconservatism present these phenomena as a significant threat to the American way of life. Their words are filled with anxiety for the future of American society, which is instilled with the positive meaning of the idea of open borders, and which is becoming permeated with alien cultures and losing its own cultural identity. Starting with an explanation of the essence of the American nation's homogeneity, this article presents the threats which come with the 'mixing' of cultures and liberal immigration as well as phenomena directly linked to such immigration, namely the problem of terrorism and Islam.
\end{abstract}

Paleoconservatism, a conservative philosophy in the United States, very often arouses mixed feelings, not only because of its name, which is often identified with 'backward' and 'old-fashioned' views, but also due to its negative attitude towards the liberal world order, promotion of which is widespread in the U.S. More precisely, this movement is viewed as a dominating anti-immigration propagator on the conservative political map in the U.S. It disagrees, as Edward Ashbee underlines, with movements which belong to the so-called 'immigrationist' camp, such as libertarianism or the Christian Coalition (Ashbee, "Immigration..." 73-74). It would not be accurate to say that the neoconservative movement prevails over the American political scene, since in Americans' minds and political writings, paleoconservatism is treated mainly as being in opposition to its activities. According to paleoconservatives (known as 'paleos'), the pro-large-scale-immigration politics adopted by the American government threaten American society on many levels of its political, social and cultural life.

In this work we will look into one of the key issues in paleoconservative discourse. The words of paleos attempt to sober up society by presenting the negative or even disastrous side of the phenomena. Paleoconservatives provide their readers with a series of arguments explaining why massive numbers of immigrants cannot be accepted. In doing so, they are guided by a variety of premises proving its 
harmfulness - ranging from practical, economic and social reasons to cultural and moral justifications. They believe that liberal immigration contributes to terrorism and 'totalitarianism,' and regard its proponents as well as executors as conspirators. Arguments in favor of unrestricted immigration are firmly rejected by paleoconservatives because to them large-scale immigration is nothing more than a step towards the destruction of the American way of life. Their negative view of the phenomenon of immigration mainly comes from paleoconservatives' tendency to pass value judgments on a specific character of American culture as well as to be in favor of regional community instead of centralization.

\section{The specific white ethno-cultural model of American identity}

In order to present the paleoconservative point of view it is necessary to refer to Edward Ashbee's article in Politics, in which the author analyses four models of American identity that are perceived or understood differently by conservatives. He classifies paleoconservatives in the camp promoting partly an ethno-cultural model which shares much of the WASP vision and partly the white ethnic model that identifies American nationhood with the attributes of European white ethnic notions of community and the establishments of the Founding Fathers (Ashbee, "Immigration..." 77; Ashbee, "Politics of Paleoconservatism" 75). Moreover, in paleoconservatives' writings, there are thoughts similar to those of John Jay's. He wrote in The Federalist Papers, No.2 in 1787 that Americans "are one united people - a people descended from the same ancestors, speaking the same language, professing the same religion (...) and very similar in their manners and customs" (Jay). Social identity appears here to be strongly linked not only to a way of living but also to skin color. Paleoconservatives follow Jay's thinking, although racial unity of the nation is understood ambiguously nowadays. They do not hesitate to claim, as well, that "any change in the racial balance must obviously be fraught with consequences for the survival and success of the American nation" (Brimelow 264). They even say that "the United States is a European country and that Americans are part of the European people" (Francis, Statement of Principles) and Euro-America is the most accurate name to call the nation (Fleming, "Short Views" 11).

Chilton Williamson underlines that it is a widespread myth that America was constructed on the foundation of open borders and immigrant cultures. America was a result of the colonial experience of Great Britain. As Williamson writes in his book, all the political and cultural institutions of coming-into-being America were British, and basic regional variations still visible nowadays are the consequence of a heritage adapted from the British Isles. Williamson points out that many of the significant personalities among the Founding Fathers, from Jefferson to Washington, were either undecided or unsympathetic toward immigration, the effect of which, as they supposed, would be the destruction of the ethnic and cultural 'structure' (Williamson, The Immigration Mystique... 30-32).

The advocates of 'liberal' immigration policy claim that the only true Americans are Indians, while the rest of the inhabitants are immigrants or the descendants of immigrants. According to Wayne Lutton, this view implies that America is only a piece of land or only a geographic expression of a continent. He disagrees with it 
categorically, saying that "America was not found ready-made, waiting for habitation by the Pilgrims who arrived on the Mayflower. Rather, they were the forerunners of a new people and a new nation, and brought what became America to this land." He goes further, arguing that it would be even proper to call Indians not "Native Americans" but maybe "Siberian-Americans," since they are the descendants of wanderers who were from Asia (Lutton, Tanton 159).

One may say that there are mechanisms, for example a policy of assimilation, that help immigrants to adapt into American society 'in a safe way.' Paleoconservatives are definitely its advocators. There are, however, voices that criticize the assimilation because it evokes unpleasant historical associations. Alan Wolfe, a sociologist, describes assimilation as "a form of symbolic violence. (...) assimilation is disruptive and heartless, the stuff of tragedy" (Wolfe 30-31). Nathan Glazer points out that the majority of Harvard students react in a negative way when they hear this word and underlines that "neither liberals nor neoliberals, conservatives nor neoconservatives, have much good to say about assimilation, and only a branch of paleoconservatism can now be mustered in its defense" (Glazer 123). And it is true that paleos would shout: "Assimilation today, assimilation tomorrow, assimilation forever." These words correlate with the stand of Governor George Wallace, who said in 1963: "Segregation today, segregation tomorrow, segregation forever." What did Wallace try to imply? And what do paleos want to express now? What connects them all is the belief that differences between races exist and it is impossible to get rid of them. Paleoconservatives simply defend, we need to say, the superiority of Western culture, as it is able to protect itself against the negative influences of any alien cultures (Francis, "Prospects for Racial..."). Conservatism is for static political and economic arrangements, since it slows or mitigates dynamic changes in society. This is why paleoconservatism supports tradition, custom and order as well as the concept of assimilation, which, according to them, is essential. If future generations are devoted to one tradition, they will be able to survive and be strong.

However, what worries paleos is the fact that the real understanding of assimilation is distorted and the idea of the whole process has changed throughout the years. The paleoconservatives try to dispel the second myth that is connected with assimilation. Reality proves that what is truly happening now is not assimilation, but a process that should be described as amalgamation. As a result, Americans and newcomers undergo a double cultural transformation by deriving and applying customs or traditions from each other (Fleming, "El Gringo y El Mexicano" 11). What is the most frightening, the opposite process of immigrants" "adaptation" can be observed, as Buchanan says, in which elites do not want immigrants to become Americans, but the U.S. to comply with the immigrants' needs so that the state can become a "stew of all languages, faiths and cultures of the world" (Buchanan, State of Emergency... 220-221). Samuel Francis points out the fact that some races are unable to assimilate. He uses such words: "The civilization that we as whites created in Europe and America could not have developed apart from the genetic endowments of the creating people, nor is there any reason to believe that the civilization can be successfully transmitted to a different people" (Francis, Shots Fired... xii). The vision of a white minority scares paleo sand forces them to scream about the loss of American identity. Numbers may speak for themselves; for example, Los Angeles is 
now over 50-percent Latino and white children are only eight percent of the school population (McGrath 16).

What becomes clear here is the statement that mass-immigration cannot be regarded as a part of American tradition. According to paleoconservatives, mass-immigration has many faces and disturbs the image of America in which small towns and neighborhoods are represented and celebrated as the authentic American cultural heartland (Ashbee, "Immigration..." 77).

\section{Immigration as a moral and socio-economic issue}

Immigration is a matter that is treated by paleoconservatives from different perspectives - from moral, social and economic ones. When it comes to morality, Chilton Williamson, one of the leading paleoconservatives, writes that the modern mentality is unfortunately prone to label issues of a moral and historical character as "policy issues." Immigration is included therein while it should be perceived mainly in a moral context. Moral criteria are applied only in order to establish that protection against immigration is immoral, but these kinds of arguments are doubtful because they come from specific interest groups such as the U.S. Chamber of Commerce, ethnic organizations, human rights activists and "professional ideologists" of all persuasions, who see nothing but their own interests (Williamson, "Promises to Keep" 102). Williamson considers immigration in moral rather than economic terms and looks at the issue from a 'deeper' perspective. The moralizing surrounding the problem of immigration is created by its advocates, who remind society that America is "a nation of immigrants" and a "universal nation," and for this reason it would be un-American or,in other words, "immoral" to reduce the influx of foreigners to the country (Williamson, The Immigration Mystique... 30-32). Does this mean that to be moral in American society one needs to be a pro-immigration advocator? According to paleos, the answer is affirmative, as this is a commonly acceptable attitude and it would be a sin to think otherwise.

David A. Hartmanis among the paleoconservatives who emphasize the socio-economic side of the problem. He claims that the great influx of immigrants has caused a nationwide decrease in salaries in the American middle class, because immigrants, being a source of cheap labor, constitute a competitive workforce. They do, indeed, work in professions which Americans are reluctant to take up, but this reluctance has occurred only because Americans demand reasonable remuneration. At the same time, the newcomers have doubled the crime rate, and while doing so, they also take advantage of the benefits that are financed by taxpayers' money. Many of them then become naturalized and thus qualify for special state assistance (Hartman, "Reflections..."). Thomas Fleming, another prominent paleoconservative, has provoked controversy with his nativistic-sounding statements marked by opposition to large-scale immigration to America. In these statements, Fleming maintained that immigration constituted a source of depravity and corruption (Fleming, "Short Views" 10-11, 24-25).

Williamson stresses the fact that the strength of immigrants comes in particular from the 1965 Immigration Act which reformed U.S. entry rules, did away with immigration quotas and opened the door wide for Asians, Africans, Latinos and other 
non-Europeans. In Williamson's opinion, assimilation is out of the question. The failure of it is evident in the example of Mexicans living in the U.S. They are interested in secession from America as a whole, in commanding part of the U.S.'s territory and in merging this territory with Mexico or creating a wholly new nation of Atzlan (Williamson, "Promises to Keep" 103). Fleming observes that although the European influence - the same influence that was brought by the settlers who would build the America of the future - is noticeable in Mexicans, their cultural consciousness is different from that of Americans in general, being full of violence and corruption. Both Fleming and Williamson agree about the disastrous influence of this alien culture on American soil. It is not difficult to predict, claims Williamson, what the reconquista of former Mexican territories would mean for states like New Mexico or California, taking into consideration the Mexican tradition "of self-indulgent violence, sadism, lawlessness, intemperance, intolerance, and irresponsibility" that is already noticeable in Mexico itself (Trotter 25-28).

Such a perception of the immigration problem by paleoconservatives is coupled with their aversion towards centralism. As claimed by Williamson, large populations mean tight regulations, and tight regulations are inseparable from large governments, which become increasingly centralized up to the point of removing subsidiary power and jurisdiction within local governments (Williamson, "Promises to Keep" 97-98, 102). Paleoconservatives celebrate American historio-cultural regionalism, which they associate with the tradition of the Old South, reducing the power of the presidency and the welfare state and keeping the family institution autonomous from the government's influence (Scotchie 50-55, 96-98).

\section{The essence of a local ethnicity and nation's homogeneity}

Opposition to immigration to the U.S. is particularly vocal in the pages of Chronicles magazine. This periodical has been the stronghold of paleoconservative thought since 1977, and is subsidized by the Rockford Institute of Rockford (Illinois). Initially known as Chronicles of Culture, the paper has been said to be in the hands of the successors of "old pre-war middle-west followers of isolationism," whose views coincided with the views of the traditionalists of the South. Among the authors involved with Chronicles, one name stands out: the name of the late Samuel Francis, who in 1986 wrote his thoughts on McCarthyism. Therein he stresses that the American nation will last and retain its social structure and political culture only when Joe McCarthy and his views are followed (Francis, "The Evil..." 16-21).

As mentioned above, America is understood by paleoconservatives as being a nation with fundamentally Anglo-Saxon roots, and in order to be maintained as such, it is necessary for it to introduce a restrictive immigration policy, like the one that existed from the 1920s to the mid-1960s. Paul Gottfried substantiated the negative attitude towards immigration by referring to such leading figures in early American history as Alexander Hamilton, Thomas Jefferson, James Madison, John Jay, and Benjamin Franklin, all of whom opposed liberal immigration to the U.S. and all of whom warned against newcomers of various cultural backgrounds (Gottfried 164).

As for the problem of aliens on U.S. territory, following the words of Chilton Williamson, one discovers that for paleoconservatives it is homogeneity that is part of 
the American tradition, not assimilation. Until the Civil War, the U.S. was a nation consisting mostly of people of North European ancestry. Only afterwards did 'multiculturalism' become important or recognized as essential. In fact, paleoconservatives consider multiculturalism to be a sign, if not proof, of America's weakness. The present inhabitants of the U.S. have, on the whole, only a very limited resemblance to their predecessors, who tended to be full of optimism and energy. Rather, they are "old people" who are bored, devoid of faith in their roots and tradition and stripped of their beliefs (Williamson, "Promises to Keep" 102). They search for material goods and individualism in all spheres of life.

Williamson's statements are developed into a wider concept. Francis refers to people who govern in the U.S. and draws attention to their way of imposing power. He clearly defines the enemy of homogenous Western culture - everything that wants to nullify the power of it. We read: "The lifestyles, aspirations, and values of the current elite are bound together, rationalized, and extended by what may be called the 'cosmopolitan ethic.' This ethic expresses an open contempt for what Edmund Burke called the 'little platoons' of human society - the small town, the family, the neighborhood, the traditional class identities and their relationships - as well as for authoritative and disciplinary institutions - the army, the police, parental authority, and the disciplines of school and church. The cosmopolitan ethic, reversing a Western tradition as old as Aesop, finds virtue in the large city, in the anonymous (and therefore 'liberated') relationships de-classed, de-sexed, demoralized, and deracinated atoms that know no group or national identities, accept no given moral code and recognize no discipline and no limits. The ethic idealizes material indulgence, the glorification of the self, and the transcendence of conventional values, loyalties, and social bonds. At the same time, it denigrates the values of self-sacrifice, community, and moral and social order" (Francis, "Message from MARs..." 302).

Similar views can be found in Jack Trotter's review of Immigration and American Future, a book edited by Chilton Williamson Jr. According to Trotter, America used to be capable of assimilating large numbers of immigrants without significantly changing its identity thanks to the nation's attachment to its own tradition and morals (Trotter 25-28). Such mass assimilation is not feasible at present, though. Trotter cites Fleming's statement on culture: "Any culture," he writes, "that expects to absorb a large population of aliens must have a coherent sense of itself." This sense includes a common language, moral and religious traditions and a deep awareness of one's own history. Common faith in 'democratic values' and pursuit of material wealth will not suffice. According to paleoconservatives, America should be ethnically heterogeneous and nationally homogenous, or, as explained by Thomas Fleming, "rich in local and ethnic diversity, but at the same time identifiable in national terms" (Fleming, "Short Views" 11). The character of America is not uniform but heterogeneous, in the sense that every state and region is unique while contributing to one nation.

Unfortunately, what bonds Americans today is "mass culture," which paradoxically "damages America's character." According to Fleming, "mass culture" is not rooted in "regional and local custom, in networks of kinship, deference, and duty." It is a culture that is promoted and spread mainly by electronic media and formed by a small elite that is devoid of roots and made up of capitalistic profiteers, Hollywood producers with their hirelings, advertisement and entertainment industries, academic intelligentsia and music producers who provide musical background for 
idle collective fantasies. Such "culture" stands little chance of surviving an immigration program of unprecedented character (Trotter 25-28).

\section{America as the threatened part of the West and proposed solutions}

According to paleoconservatives, different cultures may pose a threat to one another, and this threat can be noticed in the case of immigration. The United States, an element of the West, is threatened from within by people who do not belong to the same culture. The process that has been proceeding may result in within-border cultural arguments or, even worse, the 'conquest' of the West by aliens. Patrick Buchanan recalls Esau in the Old Testament, who sold his birthright to his brother Jacob for a bowl of pottage, and also recalls Jesus's parable of a wedding feast which the guests failed to attend, so the king invited random strangers. Relating this story to our times, he writes that people of the West are dying out and spare space in the House of the West will not be empty for long. The space prepared in America for the 40 million unborn children we have lost since the Roe versus Wade court case has been filled by poor people from Asia, Africa and Latin America. A similar situation is taking place in Europe - since Europeans have largely given up bearing children, the space prepared for them will be taken by strangers (Buchanan, The Death of the West... 97).

Justifying a dislike for immigration, Samuel Francis writes on cultural contradictions and their unpleasant consequences. In his article titled "Immigration = Totalitarianism," he describes an incident at the University of Berkeley when individuals belonging to the Berkeley Conservative Foundation were beaten up, received death threats in some cases, and had stolen from them no fewer than 3,000 copies of the paper which they had published. The attack was sparked by an article printed in this newspaper concerning MECha (Movimiento Estudiantil Chicano de Aztlan) - the Chicano Student Movement of Aztlan - which, in Francis's words, is interested in returning to and rebuilding the old homeland of Aztlan, where these protestors' Aztec ancestors had been able, unopposed, to rip out living peoples' hearts in human sacrifices, without paying any attention to Western law or civilization. The perpetrators were the very members of MECha who had long stressed its racial character, demanding the liberation of "the bronze continent by the bronze people." The leader of the aggrieved group summed up the incident clearly: "This is terrorism, pure and simple." Francis notes that what happened was an exact reflection of the political culture existing south of the U.S. border.

However, the culture upon which the U.S. was built is different. "Democracy," "freedom of speech," "color-blind society," "the rule of law" - these are not terms referring to a universal culture that is common for all. Instead, they arise from a specific civilization, Anglo-Saxon civilization, which indeed once conquered the "bronze continent," and which is the fundamental reason for creations like Berkeley having originally come into being. These terms are not known to most societies outside the West (Francis, "Immigration...").

Buchanan presents a visionin which the entire West is in danger, also as a result of its own decadence (Buchanan, The Death of the West... 118-141). How, then, should one act? Should one start to apologize and try to appease the enemies? Williamson devotes 
part of his manifesto to explaining legal steps towards stopping illegal immigration. He wants to motivate readers to take action: "In the case of the present immigration crisis, however, it seems that time is actually on the side of the restrictionists, if only they are determined to make the best possible use of it" (Williamson, "Restrictionists..."; Hartman). Buchanan suggests a psychological transformation as the solution to this problem. He states that if the West hopes for a long-term existence, it had better regain its brave faith from the times of its youth, for this is the way in which nations or religions either rule or are ruled (Buchanan, The Death of the West... 141-142). Williamson, in another essay of his, strikes a similar note. Referring to the vision of the United States as the collective messiah of the world through its own pure intentions, he claims that if the U.S. manages to crucify itself, there will be no resurrection and no apostles to disseminate the faith. There will only be the Third World left (Williamson, "Promises to Keep" 104). Trotter cites Guido Vignelli ${ }^{1}$, who claims that the correct understanding of Christian moral tradition allows "the preferential option for a nation." Pope John Paul II confirmed in 1985 that the nation is "a spiritual heritage" and that Christians are obliged to give testimony to maintain it as well as develop it. The Pope stressed that it is an "important task," "especially so for those who have to defend their own existence and their deepest identity (...) against the risk of being destroyed from outside or against disintegration from within" (Trotter 25-28).

To those for whom these arguments fail to appeal, Williamson would probably seek to address a different critique of immigration, one that presents an environmentalist's point of view: "Advocates of immigration at present or elevated levels repeat ad nauseam that immigration is 'an American tradition.' Well, so are spacious skies, amber waves of grain, wide-open spaces, the open range, and the wilderness of mountain, desert and plain. Can anyone really imagine America without them? (Pause for reflection). Can anyone really imagine America without another thirty million Mexicans, six million Iranians, ten million additional people from the Caribbean, and three or four million future refugees from the Soviet Union? (I thought so)." He strengthens his argument by pointing to the fact that the most polluted region in America is situated along the border which it shares with Mexico (Williamson, "Promises to Keep" 100-101).

To sum up, paleoconservatives ask for legal steps as well as changes in people's attitudes. George Nash quotes the most suitable words here, the words of Ortega y Gasset: "The simple process of preserving our present civilization is supremely complex, and demands incalculably subtle powers" (Nash 55).

\section{Immigration, anti-Americanism and terrorism}

The threat of terrorism is also taken very seriously by Francis. It is an issue closely linked to the immigration process. While commenting on the 2001 terrorist attacks

1 Guido Vignelli - an Italian writer, author of San Francesco antimoderno and editor of Perché non festeggiamo l' Unità d' Italia, L'invasionesilenziosa. L'immigrazionismo: risorsa o complotto? He is the vice-president of the Lepanto Cultural Center - a non-profit organization independent of political parties and economic power centers. On its webpage one can read that the institution "stands for the principles and institutions of Christian Civilization as well as represents a reference point of conservative-traditional minded thought and action" (more information at http://www.lepanto.org/cultcent.htm, access: 12.01.2013). 
on the World Trade Center, Francis points out that the background against which the attacks should be examined is that of mass immigration and the irresponsible immigration policy implemented for the last 30 years (the comment was made in 2001). But this is a context which nobody - from President Bush to experts interviewed just after the attacks - dared to mention. It was the American and Israeli foreign policy that created the anti-American hatred culture in North Africa and the Middle East. And as immigration increases, this culture will naturally be transferred. Terrorism will find safe havens in immigrant subcultures.

While criticizing an article in The New York Times, Francis stresses that it is not Adidas clothes worn by immigrants that prove someone's Westernization. If Westernization exists, it will be demonstrated through a person's beliefs, among which, as far as the West is concerned, there is no room for Islam. One should not hope that immigrants will change their beliefs, either. The terrorists who brought about the 9/11 tragedy acted in their everyday lives exactly like any other Americans. However, the hatred for the Americans whom they met remained within them. They remained the enemies of the West. For this reason, America may bomb Afghanistan or any Arab or Muslim country and wage wars outside its borders until it wears itself down, but until it can understand the issue of immigration and ethnic minorities, the problem of terrorism will remain unresolved (Francis, "Mass Immigration...").

\section{Paleoconservatism and Islam}

Beside the paleoconservative critique of immigration also appears the critique of another related threat - Islam. Buchanan provides readers with some statistics. He writes that Christian communities are dying out across Europe, churches are becoming empty and mosques are filling up. There are already five million Muslims in France alone, and in the whole of Europe Muslims now number between 12 and 15 million. In Germany there are 500 mosques. Islam has replaced Judaism as the second-largest religion in Europe. Christianity's low tide is yielding to Islam's rising tide. In 2000, Muslims outnumbered, for the first time, Catholics around the world (Buchanan, The Death of the West... 118). Although technologically and economically the West surpasses the Islamic world, the latter has retained something that the West no longer possesses - the readiness to beget children and the will to maintain one's own civilization, culture, family and faith (Buchanan, The Death of the West... 138-139). Jacek Koronackipoints out in his article that Harold O.J. Brown, an evangelical theologian and writer, agrees with Buchanan, saying that Islam is able to achieve its goals using the Muslim version of Volkerwanderungen which once crushed the Roman Empire in the West. Rapid population migrations can threaten even Israel. Shouldn't we then talk about "invasion through migration"? As an example, Brown gives the growth of the Muslim population in Germany and France (Koronacki, "Buckley...").

In light of the above, one should then ask why Islam constitutes a threat and why there is no adequate solution. In one issue of Chronicles, and on the website of Orthodoxy Today, James George Jatras ${ }^{2}$ wonders if Islam can be called (as George

2 James George Jatras - prior to his Senate work, he served as a Foreign Service Officer with the US Department of State, specializing in Soviet affairs and Eastern Europe and public diplomacy. He also served as a Consular Officer in Mexico, a frequent speaker, panelist and seminar participant on numerous topics at venues such as the Heritage Foundation, the 
W. Bush called it) a religion of peace. He claims that the idea and practice of holy war lie in the core of Islamic doctrine (Jatras). R. Cort Kirkwood, in his article in The New American, mentions Srdja Trifkovic, Chronicles's foreign affairs editor, who views Islam in a similar way. He believes that it is not quite a religion, not quite an ideology. Furthermore, he firmly maintains that in order to understand the history of Islam's contact with non-Muslims, one needs to perceive Islam itself in the way that modern totalitarian ideologies are perceived, instead of just focusing on Judaism or Christianity (Kirkwood).

As for the juxtaposing of Christianity and Islam, another paleoconservative thinker, Philip Jenkins, describes in the pages of Chronicles what to him is a significant dissimilarity between Islam and Christianity. Islam finds the whole Christian idea of God's incarnation terribly sacrilegious, has a negative approach to the material world, and portrays Jesus Christ as an austere ascetic. The rejection of God's incarnation has made Islam unable to maintain balance, and its idealism that negates the world carries within it the propensity for fanaticism (Koronacki, "Jubileusz..."). Although Trifkovic does not say so directly, he finds Islam worse than the West. The "fruits" of Islam, according to Trifcovic, warrant the attribution to them of qualities like "barbarian, irrational, primitive and sexist." Islamic scriptures, 1,400 years of practical experience and its founder's example all point to the aggressive character of Islam's followers and to its terrorist sympathies. As a political ideology, Islam is in favor of creating a society that remains under the total control of religion; a society which prepares human resources made up of people who are ready to shed blood. It is difficult to reject such a critique of Islam just because it is formulated by the West, since Islam treats everything that is non-Islamic (culture, civilization and tradition) as 'infidel' and, as such, unworthy of existing. Trifkovic adds that hostility towards Islam is natural when it comes to defending one's land, family and culture, and nobody should create barriers for this kind of hostility (Trifkovic, "Dinesh...").

How did it happen, then, that the West faces infiltration by what appears to be such an obvious enemy? After World War I, the West started to convince itself that there existed a 'mild Islam.' As time went by, the West promoted, especially, those Islamic countries which declared peaceful intentions towards Israel or those which had rich deposits of oil. Another cause is the situation of the West itself. Brown claims that people of the West are tired. Entire populations are dying out while Muslims are undergoing a demographic explosion. Meanwhile, most Christians seem not to be bothered by the fate of either their religion or their own nations. And those who are genuine believers do not see hope for the present state of the West (Koronacki, "Buckley..."). Trifkovic identifies secularism as the cause of this indifference. It is secularism that removed all Christian ideas from the social, geographical and cultural sphere. However, Islam has not changed (even if Christianity has) and if Muslims do not succumb to westernization - if they do not surrender to relativism, to skepticism, to a false interpretation of their own religious commandments, or to the desire to ignore such commandments, and if they do not become Christianized,

International Strategic Studies Association, the Ethics and Public Policy Center, and the Rockford Institute (more information at http://www.squiresanders.com/james_jatras/, access: 12.01.2013). 
by a process for which the West would have to acquire a renewed spiritual and moral strength - then there will be serious consequences. The West will be left with the choice of either defending itself or giving in to Islam (Trifkovic, "Conclusion...").

$$
* * *
$$

Paleoconservatives speak in defense of American identity by refuting arguments for immigration and promotion of multiculturalism. In their deliberations, they stress the essence of American society's coherence, resorting at the same time to local ethnicity. The words of paleoconservatives sound like sermons which are supposed to make people realize the essence of the nation's homogeneity, today's society having become, by contrast, engrossed in the reality created by the media and in the false understanding of assimilation proposed by 'pro-immigrationists.' The best summary of this piece is Buchanan's premise given in his answer to a very significant question: "Does it matter who was the 300 millionth 'American'? Indeed, it does. If it was a baby born to an American, that is wonderful news.If it was a baby born to an illegal alien, it means we have lost control of our borders. And as Ronald Reagan said, a country that can't control its borders isn't really a country anymore" (Buchanan, America 2050...).

\section{References}

Ashbee, Edward. "Immigration, National Identity, and Conservatism in the United States." Politics18: 1998 (2): 73-80.

Ashbee, Edward. "Politics of Paleoconservatism." Culture \& Society 37: 2000 (3): 75-84.

Brimelow, Peter. Alien Nation: Common Sense About America's Immigration Disaster. New York: Harper Perennial, 1996.

Buchanan, Patrick. America 2050: A Nation of Turtles. Townhall.com, 2006. n.d. Web. 13 February 2014. http://townhall.com/columnists/patbuchanan/2006/10/20/america_2050_a_ nation_of_turtles/page/full.

Buchanan, Patrick. The Death of the West: How Dying Populations and Immigrant Invasions Imperil Our Culture and Civilization. New York: Thomas Dunne Books, 2001.

Buchanan, Patrick. State of Emergency: The Third World Invasion and Conquest of America. New York: Thomas Dunne Books, 2006: 220-221.

Centro Culturale Lepanto. Culturalcenter. CCL, n.d. Web. 12 January 2013. http:/ / www.lepan to.org/cultcent.htm.

Fleming, Thomas. "El Gringo y El Mexicano." Chronicles. November 2006: 10-11.

Fleming, Thomas. "Short Views." Chronicles. September 1986: 10-11, 24-25.

Francis, Samuel. "The Evil That Men Do: Joe McCarthy and the American Right." Chronicles September 1986: 16-21.

Francis, Samuel. "Immigration = Totalitarianism." VDARE.COM., 2001. n.d. Web. 13 January 2013. http://www.vdare.com/francis/radical.html.

Francis, Samuel. "Mass Immigration Let Terrorists Operate." VDARE.COM., 2001. n.d. Web. 13 January 2013. http:/ / www.vdare.com/francis/specter.htm.

Francis, Samuel. "Message from MARs: The Social Politics of the New Right." Conservatism in America since1930. Ed. Gregory Schneider, New York: New York University Press, 2003.

Francis, Samuel. "Prospects for Racial and Cultural Survival." American Renaissance 6: 1995 (3). Web. 10 April 2014. http://www.amren.com/ar/1995/03/index.html\#cover. 
Francis, Samuel. Shots Fired: Sam Francis on America's Culture. Vienna, Virginia: Fitzgerald Griffin Foundation, 2006.

Francis, Samuel. Statement of Principles, n.d. Web. 20 March 2013. http://conservativetimes. org/Conservative_Resources/PaleoConservatism.htm.

Glazer, Nathan. "Is Assimilation Dead?" Interminority Affairs in the U.S: Pluralism at the Crossroads (Annals of the American Academy of Political and Social Science). Ed. Peter I. Rose. California: Thousand Oaks, 1993: 122-136.

Gottfried, Paul. "Reconfiguring the Political Landscape." The Paleoconservatives: New Voices of the Old Right. Ed. Joseph Scotchie. ed. New Brunswick: Transaction Publishers, 1999.

Hartman, David A. "Reflections on Immigration Reform." Chronicles November 2007: 24-25.

Jatras, James George. "The Muslim Advance and American Collaboration." OrthodoxyToday.org 2001. Web. 3 January 2013. http:/ / www.orthodoxytoday.org/articles6/JatrasMuslim.php.

Jay, John. The Federalist Papers, no. 2, 1787. Founding Fathers Homepage, n.d. Web. 3 January 2014. http:/ / www.foundingfathers.info/federalistpapers/fedindex.htm.

Kirkwood, R. Cort. "Canada Ejects Serbian-American Scholar, Stops Speech at University." The New American. The New American Online, 2011. Web. 5 January 2013. http:/ / www.thenewamerican.com/world-news/north-america/item/10630-canadaejects-serbian-american-scholar-stops-speech-at-university.

Koronacki, Jacek. "Buckley o Kuehnelt-Leddihnie, Chronicles o problemie islamskim." Arcana 1999 (5): 29.

Koronacki, Jacek. “Jubileusz Chronicles, czyli zwycięstwo Tyrmanda." Arcana 2002 (4/5): 46-47.

Lutton, Wayne, Tanton, John. The Immigration Invasion. Petoskey, MI: Social Contract Press, 1994.

McGrath, Roger D. "Paradise Lost.” Chronicles. November 2008: 14-18.

Nash, George. The Conservative Intellectual Movement in America Since 1945. New York: Basic Books, 2008.

Scotchie, Joseph. Revolt from the Heartland: The Struggle for an Authentic Conservatism. New Brunswick, NJ: Transaction Publishers, 2002.

Squire, Sanders. James George Jatras. SS, n.d. Web. 12 January 2013. http://www.squire sanders.com/james_jatras.

Trifkovic, Srdja. "Conclusion to the Sword of the Prophet: What to Do?" Srdja Trifkovic Site, n.d. Web. 6 January 2013. http:/ / trifkovic.mysite.com/article.html.

Trifkovic, Srdja. "Dinesh the Dhimmi: Jihad's Fellow - Traveller's Agenda." FrontPage Magazine, 2007. n.d. Web. 6 January 2013. http://archive.frontpagemag.com/read Article. aspx?ARTID=474.

Trotter, Jack. "After the Deluge (Review: Immigration and the American Future)." Chronicles, March 2008: 25-28.

Williamson, Chilton, Jr. The Immigration Mystique: America's False Conscience. New York: Basic Books, 1996.

Williamson, Chilton, Jr. "Promises to Keep." The Paleoconservatives: New Voices of the Old Right. Ed. Joseph Scotchie. ed. New Brunswick: Transaction Publishers, 1999.

Williamson, Chilton, Jr. "Restrictionists Have the Political Momentum - For Now." Chilton Williamson, Jr., Columns.Middle American News, n.d. Web. 13 January 2013. http:/ /www. manews.org/williamson/0907.html.

Wolfe, Alan. “Alien Nation.” The New Republic. 26 March 2001: 30-31. 